\title{
AKTIVITAS FISIK DN KONSTIPASI PADA LANSIA ADVENT DI BANDUNG
}

\author{
Mediany Sitorus ${ }^{1}$, Evelin Malinti ${ }^{2}$ \\ ${ }^{1}$ Universitas Advent Indonesia \\ ${ }^{2}$ Universitas Advent Indonesia
}

Alamat korespondensi: (medianysitorus@gmail.com)

\begin{abstract}
ABSTRAK
Kemampuan melakukan aktifitas fisik pada lansia berkurang dan menimbulkan masalah kesehatan seperti konstipasi. Penelitian ini bertujuan untuk memperoleh gambaran aktivias fisik dan kejadian konstipasi pada lansia Advent di Bandung. Jenis penelitian ini adalah penelitian kuantitatif deskriptif yang bersifat analitik korelasional dan menggunakan teknik purposive sampling. Responden dalam penelitian ini terdiri dari 57 orang lansia Advent berjenis kelamin laki-laki dan perempuan yang memenuhi kriteria inklusi. Instrumen yang digunakan adalah kuesioner kuesioner aktivitas fisik lanjut usia, kuesioner konstipasi dan Bristol Stool Chart. Pengolahan data dilakukan dengan menggunakan uji Spearman. Responden memiliki tingkat aktifitas yang dikategorikan cukup, sedang frekuensi konstipasi dikategorikan jarang dengan karakteristik feses seperti sosis dan bergumpal. Hasil uji Spearman menunjukkan bahwa tidak ada hubungan yang signifikan antara aktifitas fisik dengan kejadian konstipasi serta karakteristik feses $(p>0.05)$. Aktifitas fisik yang cukup sangat penting dilakukan oleh lansia. Penelitian selanjutanya diharapkan dapat menggali faktor lain yang berhubungan dengan konstipasi pada lansia seperti asupan cairan dan nutrisi.
\end{abstract}

Kata Kunci: Aktivitas Fisik, Konstipasi, Lansia

\section{PENDAHULUAN}

Lanjut usia (Lansia) bukanlah suatu penyakit, melainkan tahap lanjut dari proses kehidupan. Jumlah lansia secara global diproyeksikan meningkat lebih dari tiga kali lipat antara 2017 dan 2050, naik dari angka 137 juta menjadi 425 juta. Proses penuaan populasi paling banyak di negara Eropa dan Amerika Utara, yaitu satu dari lima orang adalah berusia di atas 60 tahun pada 2017, dan diperkirakan pada tahun 2050 sebanyak $35 \%$ dari populasi di Eropa, 28\% dari populasi di Amerika Utara, 24\% dari populasi di Asia, dan $9 \%$ dari populasi di Afrika. Jumlah lansia di Indonesia juga semakin meningkat dari tahun ke tahun. Pada tahun 2018 terdapat $9,27 \%$ atau sekitar 24,49 juta lansia dari seluruh jumlah penduduk. Angka ini meningkat dibandingkan tahun sebelumnya yang hanya terdapat 8,97 persen atau sekitar 23,4 juta lansia di Indonesia. (Muhith dan Sandu, 2016; Department of Economic and Social Affairs, 2017; Department of Economic and Social Affairs, 2019; Subdirektorat Statistik Pendidikan dan Kesejahteraan Sosial, 2018).

Seiring dengan berjalannya waktu, secara normal penambahan usia akan menyebabkan penurunan fungsi biologis atau fisik, termasuk sistem pencernaan. Perubahan sistem pencernaan pada lansia diantaranya adalah perubahan dalam usus besar, penurunan sekresi mukus pencernaan, penurunan kelastisitasan dinding rektum, dan peristaltik kolon yang melemah, peningkatan kelokan-kelokan pembuluh darah rektum. Sebagai akibat dari perubahan sistem pencernaan ini, rektum akan gagal mengosongkan isinya, motilitas kolon menjadi berkurang, menyebabkan absorpsi air dan elektrolik meningkat, sehingga keluhan konstipasi merupakan keluhan yang sering didapat pada lansia (Maryam, dkk, 2008; Sunaryo, dkk, 2015; Muhith dan Sandu, 2016).

Konstipasi adalah gangguan saluran pencernaan dimana penderita mengalami kesulitan untuk mengeluarkan sisa-sisa pencernaan (feses), akibatnya feses menjadi keras dan ketika mengeluarkannya membutuhkan tenaga yang kuat. Konstipasi lebih banyak dialami oleh orang yang berusia lanjut karena disebabkan oleh melemahnya peristaltik usus. Penelitian Chu, dkk menunjukkan sebanyak $2699(18,1 \%)$ dari 14893 lansia di China mengalami konstipasi. Study Roque dan Ernest juga melaporkan bahwa kejadian konstipasi kronis lebih tinggi $20 \%$ pada populasi lansia dibandingkan dengan populasi yang lebih muda. Penelitian Blekken, dkk juga menunjukkan 23,4\% dari 261 lansia pada sebuah panti jompo di Norwegia mengalami sembelit dan $67,1 \%$ dari penderita menggunakan obat pencahar secara teratur. Hasil penelitian Oktariyani di Wisma Bungur Cibubur menemukan 16,67\% lansia 
mengalami konstipasi. Berdasarkan penelitian Kristamuliana di panti werdha Budi Mulia 3 Ciracas dan Budi Mulia 4 Margaguna Jakarta Selatan, 70 lansia teridentifikasi mengalami konstipasi (Bangun, 2017; Wang 2014; Girgio, dkk, 2015; Chu, dkk, 2014; Roque dan Ernest, 2015, Blekken, dkk, 2015, Oktariyani, 2013; Kristamuliana, 2015).

Para peneliti telah berupaya untuk mencari tahu faktor predisposisi konstipasi. Secara umum didapati rendahnya asupan serat dan air, serta kurangnya aktivitas fisik. Aktivitas fisik merupakan gerakan yang dilakukan oleh otot-otot tubuh dan sistem penunjangnya. Fisik lansia yang melemah sebagai akibat dari proses penuaan menyebabkan keterbatasan lansia dalam beraktivitas sehingga mengakibatkan terjadinya kelemahan tonus otot dinding saluran cerna sehingga akan terjadi konstipasi. Kurnianto juga menjelaskan bahwa latihan fisik akan berefek akut atau sesaat pada tubuh yang memengaruhi berbagai sistem, seperti sistem hormonal, sistem peredaran darah dan pernafasan, sistem pencernaan, metabolisme, dan sistem pembuangan (Raissa, 2012; Kurnianto, 2015).

Berdasarkan dukungan teori dan hasilhasil research di atas, peneliti menjadi tertantang untuk melakukan penelitian lebih lanjut tentang aktivitas fisik dan angka kejadian kostipasi pada lansia, serta pengaruhnya.

\section{BAHAN DAN METODE}

\section{Metode yang digunakan dalam} penelitian ini adalah metode deskriptif kuantitatif yang bersifat analitik. Populasi penelitian diambil dengan menggunakan teknik purposive sampling, yaitu sample dengan batasan usia lansia 60 tahun keatas yang merupaka lansia Advent di jemaat Cihampelas, jemaat UNAI, jemaat Parongpong di Bandung. Lansia yang diikutsertakan adalah lansia sehat, bisa membaca dan tidak ada gangguan mental.

Pengumpulan data didahului dengan uji etik dari KEPK FIK UNAI. Proses pengumpulan data dilaksanakan dengan cara peneliti menemui calon responden. Setiap responden diberi penjelasan terlebihdahulu tentang tujuan penelitian dan diminta untuk berpartisipasi secara sukarela dengan mengisi informed consent. Data yang diperoleh dalam penelitian ini dikumpulkan menggunakan instrumen yang terdiri terdiri dari tiga kuesioner yaitu, kuesioner aktivitas fisik lanjut usia, serta Bristol Stool Chart dan kuesioner konstipasi.
Data yang terkumpul diperiksa dan dipastikan kelengkapannya kemudian diberi kode sesuai kategori. Data yang telah ditabulasi dianalisa secara deskriptif dan uji korelasi dengan Spearman test, karena hasil uji normalitas menunjukkan data tidak berdistribusi normal.

\section{HASIL PENELITIAN}

Total responden yang berpartisipasi adalah 57 lansia dengan rentang usia 60 tahun sampai 86 tahun. Ke 57 responden terdiri dari 17 laki-laki dan 40 perempuan. Tabel 1 menunjukkan karakteristik responden.

Tabel 1 Karakteristik responden Lansia Advent

\begin{tabular}{|c|c|c|}
\hline Karakteristik & $\mathrm{n}$ & $\%$ \\
\hline Usia & & \\
$60-<70$ tahun & 43 & 75,4 \\
$70-<80$ tahun & 11 & 19,3 \\
$\geq 80$ tahun & 3 & 5,3 \\
\hline Jenis Kelamin & & \\
Laki-laki & 17 & 29,8 \\
Perempuan & 40 & 70,2 \\
\hline
\end{tabular}

Dari tabel 1 dapat dilihat bahwa distribusi responden berdasarkan umur adalah sebagian besar responden $(75,4 \%)$ memiliki rentang umur antara $60-<70$ tahun. Sebanyak $19,3 \%$ lansia berusia antara $70-<80$ tahun, dan sebanyak $5,3 \%$ lansia berusia diatas 80 tahun.

Rata-rata aktifitas fisik dan skor konstipasi serta karakteristik feses responden ditunjukkan dalam tabel 2 di bawah ini.

Tabel 2 Nilai rata-rata aktifitas fisik, konstipasi, dan karakteristik feses.

\begin{tabular}{|l|c|c|c|}
\hline \multicolumn{1}{|c|}{ Variabel } & $\mathrm{n}$ & Mean & Interpretasi \\
\hline $\begin{array}{l}\text { Aktifitas } \\
\text { Fisik }\end{array}$ & 57 & 2,58 & $\begin{array}{c}\text { Aktifitas } \\
\text { cukup }\end{array}$ \\
\hline $\begin{array}{l}\text { Frekuensi } \\
\text { Konstipasi }\end{array}$ & 57 & 2,05 & Jarang \\
\hline $\begin{array}{l}\text { Karakteristik } \\
\text { feses }\end{array}$ & 57 & 2,30 & $\begin{array}{c}\text { Seperti sosis } \\
\text { dan } \\
\text { bergumpal }\end{array}$ \\
\hline
\end{tabular}

Dari table 2 di atas, hasil analisis data menunjukkan bahwa rata-rata aktifitas fisik lansia adalah 2,58 yang termasuk dalam kategori aktifitas cukup. Rata-rata konstipasi adalah 2,05 yang dikategorikan ringan sedang karakteristik feses dikategorikan seperti sosis dan bergumpal.

Tabel 3. Korelasi antara aktifitas fisik dan konstipasi pada lansia

\begin{tabular}{|l|l|l|c|l|}
\hline Variabel & $\mathrm{n}$ & Mean & $R$ & $P$ value \\
\cline { 1 - 4 } Aktifitas Fisik & 57 & 2,58 & 0,099 & \multirow{2}{*}{0,463} \\
\hline Konstipasi & 57 & 2,05 & & \\
\hline
\end{tabular}


Tabel hasil analisis data diatas menunjukkan bahwa nilai koefisien korelasi Spearman ( $r$ ) yang diperoleh adalah 0,099 dengan nilai signifikansi $p=0,463$.

\section{PEMBAHASAN}

Secara fisiologi pada lansia terjadi perubahan masa otot yang menyebabkan berkurangnya kekuatan, ketahanan dan keseimbangan pada lansia. Hal ini mengakibatkan berkurangnya kemampuan lansia dalam melakukan aktifitas dan meningkatnya resiko jatuh pada lansia (Reuter, 2012). Namun, lansia disarankan untuk melakukan aktifitas fisik. Aktifitas fisik yang rutin dilakukan memberi manfaat kesehatan bagi lansia secara mental, emosi, fisik, sosial dan kognitif (Langhammer dkk., 2018).

Hasil penelitian ini menunjukkan bahwa ke-57 responden lansia Advent memiliki tingkat aktifitas fisik yang cukup. Sedangkan untuk tingkat konstipasi responden lansia Advent berada pada kategori konstipasi ringan dengan karakteristik feses seperti sosis dan bergumpal. Hasil uji Spearman menunjukkan bahwa $p=0,463$ yang berarti nilai $\alpha>0,05$ sehingga dalam hal ini dinyatakan bahwa tidak terdapat hubungan signifikan antara aktifitas fisik dan konstipasi pada lansia Advent. Nilai korelasi koefisien $(r)=0,099$ yang berarti bahwa terdapat hubungan positif yang sangat lemah.

Hasil penelitian ini bertolakbelakang dengan penelitian sebelumnya yang mendapatkan hasil bahwa dari 68 responden, sebagian besar lansia memiliki aktifitas yang rendah, dan lebih dari setengah mengalami konstipasi (Sari, 2016). Konstipasi merupakan keluhan umum dan tantangan kesehatan yang sering dihadapi oleh lansia.Penting bagi lansia untuk merubah pola hidup dengan meningkatkan aktifitas fisik, mengkonsumsi makanan berserat dan meningkatkan asupan cairan (Schuster, 2015). Penelitian lain yang dilakukan oleh Vargas-Garcia dan VargasSalado (2013) yang mengevaluasi aktifitas fisik, status nutrisi dan asupan makanan dengan konstipasi menunjukkan bahwa lansia yang memiliki aktifitas tinggi tidak mengalami konstipasi. Asupan makanan yang kurang dan aktifitas rendah berhubungan dengan konstipasi yang dialami oleh responden.

\section{DAFTAR PUSTAKA}

Aktifitas yang cukup pada lansia dalam penelitian ini memberikan pengaruh pada frekuensi konstipasi dimana lansia jarang mengalami konstipasi meskipun hubungan diantaranya menunjukkan nilai yang tidak signifikan. Penelitian sebelumnya yang dilakukan menunjukkan bahwa lansia Advent memiliki asupan serat yang tinggi dan tidak mengalami konstipasi sedang lansia non Advent memiliki tingkat asupan serat yang rendah dan mengalami konstipasi (Sulistiono \& malinti, 2019). Dengan demikian yang lansia Advent memiliki frekuensi konstipasi yang jarang karena aktifitas yang cukup dan asupan serat yang tinggi.

Tidak aktif secara fisik atau imobilitas membuktikan perubahan pada pola defekasi dan terjadinya konstipasi fungsional (lovino dkk., 2013). Lansia yang terlibat dalam aktifitas fisik yang tinggi memiliki kesempatan sukses dimasa tua dalam hal kesehatan fisik (Gopinath, dkk., 2018). Konstipasi pada yang sering dialami lansia berakibat buruk pada mood dan kesehatan pada umumnya. Lansia sering mengalami perubahan pola defekasi dan mengalami kesulitan untuk mendapatkan solusi (Munch, dkk. 2016).

Apabila konstipasi hanya terjadi sesekali, belum menimbulkan masalah. Namun bila konstipasi berlangsung lama dan berulang akan mengganggu. (Mounsey, dkk., 2015). Konstipasi yang dialami lansia sering merupakan akibat dari kecenderungan lansia yang kurang aktifitas, bergaya hidup sedentari, kurang asupan cairan dan kurang asupan makanan berserat (Giorgio, dkk., 2015). Penanganan konstipasi pada lansia termasuk meningkatkan aktifitas fisik, perubahan gaya hidup dan nutrisi yang cukup. Pada konstipasi kronis membutuhan terapi farmakologi (Djordjevic, 2018).

\section{KESIMPULAN}

Bedasarkan hasil penelitian didapati bahwa aktifitas fisik lansia Advent di Bandung tergolong cukup dengan frekuensi konstipasi jarang. Tidak ada hubungan siknifikan antara aktifitas fisik dengan frekuensi konstipasi. Adanya faktor lain yang mungkin menjadi penyebab konstipasi pada usia lanjut sehingga penelitian lebih lanjut perlu dilakukan dengan sampel penelitian yang lebih besar.

Bangun, A. P. (2015). Sehat Bugar pada Usia Lanjut dengan Jus Buah dan Sayuran. Jakarta: PT. Gramedia Pustaka Utama.

Chu, K, dkk. (2014). Epidemiology characteristics of constipation for general population, pediatric population, and elderly population in China. Gastroenterology Research and Practice. China: Hindawi Publishing Corporation. 1-11. 
Djordjevic, N. (2018). Causes and management of constipation in elderly people. Available online at: https://medalerthelp.org/constipation-in-elderly/

Girgio, R.D., dkk. (2015). Chronic constipation in the elderly: a primer for the gastroenterologist. BMC Gastroenterology. USA: BioMed Central 15(130), 1-13.

Gopinath, B., Kifley, A., Flod, V. M., \& Mitchell, P. (2018). Physical activity as a determinant of successful aging over te years. Scientific report. 8, (10522). https://doi.org/10.1038/s41598-018-28526-3

Iovino, P., Chiarioni, G., Bilancio, G., Cirillo, M., Mekjavic, I. B., Pisot, R., \& Ciacci, C. (2013). New onst of constipation during long-term physical inactivity: a proof of concept study on the immobility induced bowel changes. Available online at: https://journals.plos.org/plosone/article?id=10.1371/journal.pone.0072608

Kurnianto, D. P. (2015). Menjaga kesehatan diusia lanjut. Jurnal Olahraga Prestasi. 10(2), 19-28.

Langhammer, B., Bergland, A., \& Rydwik E. (2018). The importance of Physical activity exercise among older people. BioMed Research International. doi.org/10.1155/2018/7856823

Maryam, R. S., dkk. (2008). Mengenal Usia Lanjut dan Perawatannya. Jakarta: Salemba Medika.

Monsey, A., Raleigh, M., \& Wilson, A. (2015). Management of constipation in older adults. American Family Physichian. 92 (6). 500-504

Muhith, A., dan Sandu, S. (2016). Pendidikan Keperawatn Gerontik. Yogyakarta: ANDI.

Munch, L., Tvistholm, N., Trosborg, I., \& Konradsen, H. (2016). Living with constipation: older people's experiences and strategies with constipation before and during hospitalization. International journal Qualitative Study Health Well-being. 11. doi: 10.3402/ghw.v11.30732

Raissa, T. (2012). Asupan serat dan cairan, aktivitas fisik, serta gejala konstipasi pada lanjut usia. Skripsi. Bogor: Institut Pertanian Bogor.

Reuter, I. (2012). Aging, Physical Activity and disease prevention 2012. Journal of Aging Research. doi:10.1155/2012/373294

Roque, M. V., dan Ernest, P. B. (2015). Epidemiology and management of chronic constipation in elderly patients. Clinical Interventions in Aging. 913-920. USA: Gastroenterology and Hepatology Department.

Schuster, B. G. (2015). Constipation in older adults: stepwisw approach to keep things moving. Can Fam Physician, 61 (2): 152-158.

Sulistiono, J. I. D., \& Malinti, E. (2019). Frekuensi asupan makan sumber serat dan kejadian konstipasi pada lansia Advent dan Non Advent. Klabat Journal of Nursing. 1 (2):8-11

Sunaryo, dkk. (2015). Asuhan Keperawatan Gerontik. Jakarta: ANDI.

Wang, A. (2014). Hidup Sehat dan Panjang Umur. Jakarta: PT. Gramedia Pustaka Utama. 